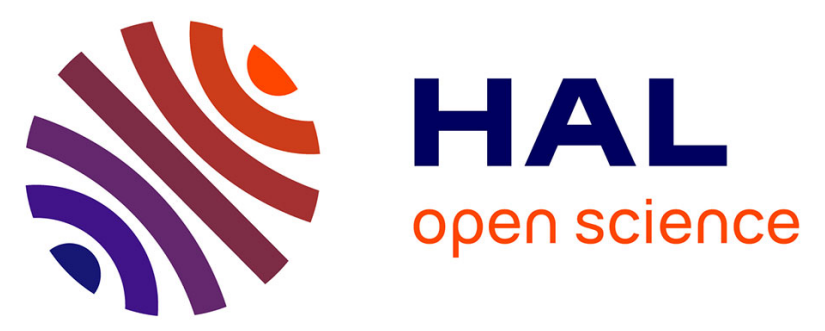

\title{
Kinetid structure in larval and adult stages of the demosponges Haliclona aquaeductus (Haplosclerida) and Halichondria panicea (Suberitida)
}

Agniya M Sokolova, Igor R Pozdnyakov, Alexander Ereskovsky, Sergey A Karpov

\section{To cite this version:}

Agniya M Sokolova, Igor R Pozdnyakov, Alexander Ereskovsky, Sergey A Karpov. Kinetid structure in larval and adult stages of the demosponges Haliclona aquaeductus (Haplosclerida) and Halichondria panicea (Suberitida). Zoomorphology, 2019, 138 (2), pp.171-184. 10.1007/s00435-019-00437-5 . hal02025390

\author{
HAL Id: hal-02025390 \\ https://hal.science/hal-02025390
}

Submitted on 10 Dec 2019

HAL is a multi-disciplinary open access archive for the deposit and dissemination of scientific research documents, whether they are published or not. The documents may come from teaching and research institutions in France or abroad, or from public or private research centers.
L'archive ouverte pluridisciplinaire HAL, est destinée au dépôt et à la diffusion de documents scientifiques de niveau recherche, publiés ou non, émanant des établissements d'enseignement et de recherche français ou étrangers, des laboratoires publics ou privés. 
Kinetid structure in larval and adult stages of the demosponges Haliclona aquaeductus(Haplosclerida) and Halichondria panicea (Suberitida)

Agniya M. Sokolova ${ }^{1,2}$, Igor R. Pozdnyakov ${ }^{3}$, Alexander V. Ereskovsky ${ }^{3,4}$, Sergey A. Karpov ${ }^{3,5}$

${ }^{1} A$. N. Severtzov Institute of Ecology and Evolution, Leninskijprosp. 33, Moscow, 119071, Russia

${ }^{2}$ N. K. Koltzov Institute of Developmental Biology, Russian Academy of Sciences, Vavilovastreet 26, Moscow, 119334, Russia

corresponding author:enfado@ya.ru; +79163337259. ORCID ID: 0000-0002-2056-1310

${ }^{3}$ St. Petersburg State University,Biological Faculty, Universitetskayaemb. 7/9, St. Petersburg, 199034, Russia

${ }^{4}$ Aix Marseille University, Avignon Université, CNRS, IRD, IMBE, Marseille, France

${ }^{5}$ Zoological Institute of Russian Academy of Science, Universitetskayaemb. 1, St. Petersburg, 199034,

Russia 


\begin{abstract}
At larval and adult stage of life cycle sponges (Porifera) possess differentflagellated cellsthat plays different role in their body. Cells of larval epithelium serve as locomotory organs, while collar cells (choanocytes) of adults have a feeding function.Here, we describe for the first time the detailed structure of the flagellar apparatus (kinetid) in larval cells and choanocytes of the demosponges Haliclona aquaeductus and Halichondria panicea, and propose schemes of its organization based on longitudinal and transversal serial ultrathin sections. The kinetid of larvae has proved to be more complicated than that of choanocytes. It includeswell-developed transverse and longitudinal cytoskeletons that strengthen the larval flagellum. The longitudinal skeleton in $H$. aquaeductus is represented by unusual structures previously understudied: large tubular rootlets made of oblique crossed fibers and connecting the kinetosome with mitochondria. We also found out the kinetid composition varies between different cell types of a highly structured parenchymella of $H$. aquaeductus. In simply organized parenchymella of $H$. panicea flagellated cells are identical and its kinetid includes a consistent additional centriole absent in choanocytes of adult sponges. We tried to evaluate the diversity of sponge larval kinetid organization based on literature data and found it variable within Haplosclerida and quite conservative within other sponge lineages.
\end{abstract}

Key words: Porifera, larvae, choanocytes, ultrastructure, kinetid 


\section{Introduction}

Invertebrates have evolved wide variety of life cycles, among which the biphasic bentho-pelagic life cycle stands out. It realizes in alternation between a small motile larvae emerging from the egg and larger benthic adult, which is often sedentary or sessile. The appearance of dispersing larval stage in evolution was obviously a great step for development of diverse life forms known for today. Investigation of larvae can shed the light on the intricate evolutionary questions as they can retain fundamentalancestral features that allow us to look in depths of time. The larva of certain invertebrates display a core set ofsynapomorphic traits and gene expression patterns that are lacking in the adult form.

Sponges (Porifera) belong to one of the most ancient metazoan lineage that represents one of the earliest branches of the animal tree (Simion et al. 2017). Sponge larvaeare regarded as sharing more traits and complexity with eumetazoans than adults (Maldonado 2004; Nielsen 2008). These facts induce to reflect who appeared first, the sponge larva or the adult. But this question is probably far from solution. Even though the sponge larva is an object of numerous thorough studies, many aspects of its biology remain largely obscure. For example, AmphimedonqueenslandicaHooper and van Soest, 2006 is one of the most-studied sponge with deciphered genome and larval gene expression patterns, but we still cannot precisely identify all types of its larval cells (MahandLeys 2017). For more complete understanding of the sponge's life morphological studies of both stages are needed. The present work is intended to contribute the knowledge about sponge ultrastructure.

We focused on sponge flagellated cells, trying to reveal how elements of the flagellar apparatus, or the kinetid are arranged. It is worth to notice that larval flagellated cells serve as locomotory (or, rarely, sensory) organs, while the flagellum inadults' choanocytes participate in water pumping. Thus, flagella are essentially important for sponges on both stages. The kinetid is composed of three main parts: a free part, or the flagellum itself; a basal intracellular part containing normally two kinetosomes (the non-flagellated one is often called accessory centriole) with attached microtubular or fibrillar rootlets; and the transition zone connecting the free and basal parts, often containing phylogenetically important structures (Moestrup 1982, 2000; Andersen et al. 1991; Karpov 2000; Barr 2001). It has been shown that kinetid structure can be used in the taxonomy and phylogeny of unicellular eukaryotes (e. g., Yubuki and Leander 2013). In sponges, kinetid is also known as a very perspective morphological phylogenetic marker, since it includes evolutionary conservative structures along with variable ones(Pozdnyakov et al. 2017; 2018). Kinetid structure of choanocytes, collar cells of adults,can be successfully superimposed on phylogenetic tree of sponges based on molecular surveys (Pozdnyakov et al. 2018), while in sponge larva it is largely understudied. 
The larval kinetid was first specially studiedby Woolacott and Pinto (1995); the authors found it more complex and more diverse than that of choanocytes whose kinetid was not well studied that time (Pozdnyakovand Karpov 2013). Some components of the flagellar apparatus were properly illustrated in many papers(Boury-Esnault 1976; Nielsen 1987; GallisianandVacelet 1991; Woolacott 1993; AmanoandHori 1992, 1994, 1996, 2001; Ivanova 1997; LeysandDegnan 2001; Uriz et al. 2001; Boury-Esnault et al. 2003; Maldonado et al. 2003; Ereskovsky andTokina 2004; UsherandEreskovsky 2005; Gonobobleva 2007; EreskovskyandWillenz 2008; Maldonado 2009; LannaandKlatau 2012; Stephens et al. 2013). Due to these studies one can reveal some distinctions between kinetids of the adult and larva, trace common characters of their arrangement and compare sponges of different taxonomic position.

Phylum Porifera comprise classes Demospongiae, Calcarea, Homoscleromorpha, and Hexactinellida with over 9000 extant species. The biggest class Demospongiae includes three subclasses: Verongimorpha, Keratosa and Heteroscleromorpha (Morrow and Cardenas 2015).

A special attention should be paid to the large and phylogenetically problematic order Haploscleridathatforms most basal branch at the phylogenetic tree ofsubclass Heteroscleromorpha(Morrow and Cardenas 2015). Kinetid structure of its representatives significantly differs. For example, Stephens et al. (2013) investigated both larva and adult of Haliclona indistincta(Bowerbank, 1866), and the provided illustrationsof the kinetid are not in accordance with previously studied haplosclerids and even genus Haliclona (WoolacottandPinto 1995; AmanoandHori 1996; LeysandDegnan 2001; Maldonado et al. 2003).

To contribute the assessment of the distribution of larval kinetid structure within polyphyletic genusHaliclona(Redmond et al. 2011), we have chosen Haliclona aquaeductus(Schmidt 1862) as an object of the current study.

Other sponge under consideration, the representative of the order Suberitida (Heteroscleromorpha), Halichondria panicea (Pallas 1766), is distantly related to Haliclona aquaeductus (Morrow and Cardenas 2015). The kinetid structure offlagellated cells of larvae in H. paniceais interesting: Woolacott and Pinto (1995) drawn an accessory centriole in kinetid scheme of the suberitidsHalichondria melanodociaLaubenfels, 1936, Halichondria coeruleaBergquist, 1967and Hymeniacidonheliophila(Wilson, 1911) (fig. 2 in their paper), while choanocytes of suberitids are supposed to be devoid of the permanentcentriole (PozdnyakovandKarpov 2016).

Kinetid of both larvae and adults of the studied species, Haliclona aquaeductus and Halichondria panicea were investigated on serial consecutive sections at TEM, the kinetid schemes were reconstructed and discussed. This research is aimed to enlarge our knowledge on the sponge flagellar apparatus and contribute to morphological basis for phylogenetic studies. 


\section{Materials and methods}

Sponges with mature larvae were collected in the Kandalashsky Bay of the White Sea (WSBS MSU) in first couple of weeks of July 2017. Larvae were gathered via glass Pasteur pippete after the sponge had been put in the tank with stagnant water. Larvae and adults' pieces were fixed and treated for transmission electron microscopy according the following protocol. For prefixation, $1 \mathrm{~mL}$ of $1 \%$ osmium tetroxide in cacodylate buffer $\left(0.1 \mathrm{~mol} \mathrm{l}^{-1}, \mathrm{pH} 7.4\right)$ was added to $3 \mathrm{~mL}$ of water containing a sponge fragment. Next, $4 \mathrm{~mL}$ of $4 \%$ glutaraldehyde in the same buffer was added and the sponge fragment was kept in this mixture for 15 min on ice in the dark. Then, the fixative mixture was replaced with $2 \%$ glutaraldehyde for $1 \mathrm{~h}$ on ice. Afterwards, samples were rinsed twice in the buffer and postfixed in $1 \%$ osmium tetroxide for $1 \mathrm{~h}$ at room temperature. The samples were then washed twice for $10 \mathrm{~min}$ in the same buffer, dehydrated in a graded ethanol series and embedded in Spurr resin. After polymerization, the resin blocks with sponge fragments were trimmed and treated with $10 \%$ hydrofluoric acid for $5 \mathrm{~min}$ to remove siliceous skeletal elements. Ultrathin sections $(60 \mathrm{~nm})$ were cut with a Leica EM UC6 ultramicrotome using a glass knife. The sections were double stained in uranyl acetate (15 min) and subsequently lead citrate ( $3 \mathrm{~min}$ ) and were observed in a JEM 1400 and Morgagni 268 D electron microscopes equipped with an Olympus Veleta digital camera. For scanning electron microcopy fixed larvae were put in series of ethanol with increasing concentration of aceton dried in critical point and observed via Quanta 250 and Hitachi S-465A microscopes.

Several larvae and choanosomal pieces collected in different time were investigated for each species.

Descriptions follow the terminology used by Andersen et al. (1991)andWoolacott and Pinto (1995).

\section{Results}

\section{Haliclona aquaeductus}

The mature larva of H.aqueductus is highly mobile ellipsoid parenchymella of nearly 500-700 $\mu \mathrm{m}$ length and 200-300 $\mu \mathrm{m}$ width. Three morphological zones can be distinguished in its body (fig. 1 a): 1) anterolateral zone covered with slightly spiral longitudinal rows of short (about 20 $\mu \mathrm{m})$ cilia; 2) tuft, or narrow (5-7 cells) ring of long (about $110 \mu \mathrm{m}$ )cilia combined in "compound cilia'(fig. $1 \mathrm{~b}$ ); 3) a non-flagellated pigmented posterior pole ringed by the tuft. The posterior pole includespigmented dark-brown ring, which is well seen against the background of the pale larva.

The surface layer is formed by single-row ciliated cells of at least three types: anterolateral columnar cells, tuft cells and flask cells. 
The most common cells are elongated narrow columnar cells(fig. $1 \mathrm{c})$. Their nuclei are basal and anucleolated, and the proximal part of flagellar axoneme isoften immersed in the apical cytoplasm (fig. 1 d). Their flagellum has an axoneme with typical $(9+2)+2$ microtubular organization. In transitional zone the central microtubules are covered with prominent central sheath (fig. 2 e-g) that becomes barely distinguishable up from this zone (fig. 2 h). Nine spokes radiate from the central sheath to the transitional cylinder, an electron-dense structure constituted by two-layered membrane (fig. 2 e-g). Central microtubules start at the same level with transitional cylinder or somewhat lower, while the sheath starts at the same level with the cylinder. More proximal from the cylinder there is usually a heterogeneous electron-dense material (fig. 2 d). Thin transverse plate (fig. 3 b), sometimes slightly inflated at the center, marks the distal end of the kinetosome, having typical $(9 \times 3)+0$ organization. Transversal cell skeleton is represented by lateral microtubules extending to the rootlets, mitochondria and cell membrane, and lateral arm (sensuWoolacottand Pinto 1995), which is constituted by microtubules associated with electron-dense material (fig. 2 a). The lateral arm is attached to microtubular organization center (MTOC) shaped as a basal foot. The distal part of the foot, bean-like cap, is attached to the kinetosome by several stalks (fig. 2 a, fig. 3 a).Nine transitional fibers (=alar sheets) attach the kinetosome to the plasmallema: each filament raises from a single triplet and connects it to the cell membrane via an electron-dense anchoring point (fig. 2 c, fig. 3 e). Longitudinal cytoskeleton is comprised of peculiar rootlets. They appear to be large hollow tubes of various diameter (probably contractive) with the surface looking crisscross-striated due to the opposite orientation of oblique fibers (fig. $3 \mathrm{c}-\mathrm{g}$ ). Rootlets start from the kinetosome and extend toward the proximal part of the cell. Bunch of asymmetric mitochondria is closely associated with the rootlets, but direct contact was not observed (fig. $3 \mathrm{f}, \mathrm{g}$ ).

Columnar cells of the tuft(tuft cells) bear a prominent single protrusion (fig. 4 b); axoneme of their flagellum iscompletely covered by the flagellar membrane. Unlike anterolateral columnar cells, these cells are often covered with glycocalyx(fig. 4b).Transitional zone arrangementcoincides with that in previous cell type, but central microtubules start more distal than the transitional cylinder (fig. 4 b). The kinetosome bears an electron-dense element with unresolved structure, which is located proximal to the basal foot and, probably, represents an accessory MTOC (4 d-f).

In tufts of studied larvae, we observed a prominent tendency to rootlets reduction. Rootlets can be completely absent or as long as half or third of the long rootlets in anterolateral columnar cells. When rootlets are lacking, mitochondria are associated directly with the kinetosome (fig. 4 $b, d, f)$.

Flagellated flask cells(fig. $5 \mathrm{a}, \mathrm{b}$ ) that wedge between columnar cells are quite rare (about 10-20 per larva) cell type. These cells form the lobopodia throughout their entire length and has 
somewhat irregular flask shape. The kinetid of flask cellshas no rootlets (fig. 5 c). MTOC associated with the kinetosome looks like a dense mass of irregular shape (fig. $5 \mathrm{c}$ ). Bicornshaped parabasal nucleus has no direct link with the kinetosome, but is often associated with a centriole (fig. 5 f). The centriole is somewhat smaller than the kinetosome; its location in relation to the kinetosome is not standing. We failed to figure out whether this centriole is a constant element of the cell or match a certain state of cell cycle.

Choanocyte chamber of adult $H$. aquaeductus consists of choanocytes (fig. 6 a, b) of roundish shape. Its kinetid hastransverseplate more prominent than in larval cells (fig. 7a). The kinetosome is associated with the Golgi apparatus by thin fibrillary rootlets (fig. $7 \mathrm{~b}$ ), and sometimes the vesicles rest on the kinetosome (fig. 7 b). Its kinetosome serves as MTOC for radially arranged microtubules (fig.7c, e), and basal foot is absent (fig. 7d).

\section{Halichondria panicea}

H. panicea develops a middle-size (about $300 \mu \mathrm{m}$ ) ellipsoid bright-yellow parenchymella (fig. 8 a) covered by loosely arranged identical flagellated cells (fig. 8b, c). Its flagellum emerges from a pit, and the pit's walls contain excretory granules (fig. 9 a).

Its larval kinetid is closely associated with pear-shaped nucleolated nucleus by thin rootlets projected from the distal part of kinetosome (fig. 9a). The Golgi apparatus lies on the rootlets, so does the accessory centriole(fig. 9 a, b). Mitochondria are scattered in the cytoplasm, mainly in distal half of the cell (fig. 9 d). In the transitional zone of the flagellum one can see the transitional cylinder (fig. 9 b). Central axonemal microtubules start at the level of the cylinder (fig. 9 b). Axial granule hangs on the filaments at the level of the plasma membrane (fig. 9 b). Nine transitional fibers attach the kinetosome to the cell membrane (fig. 9 b). Long (about 160$190 \mathrm{~nm}$ ) cone basal foot with roundish cap gives rise to the transverse skeleton formed by lateral microtubules (fig. 9c).

Choanocyte chamber of adult H. panicea (fig. 10 a)is constituted by irregularly arranged flattened choanocytes that have kinetosome-nucleus connection. The Golgi apparatus lies close to the nucleus (fig. $10 \mathrm{~b}$ ). The rootlets are much more short and rare than in larvae (fig. $10 \mathrm{~b}, \mathrm{c}$ ); the accessory centriole is absent. Basal foot is also shorter, and there is small additional MTOC (satellite) on the opposite side of the kinetosome (fig.10 b-d). As in other sponges, the flagellum includes so-called 'dark zone' (PozdnyakovandKarpov 2015, 2016;Pozdnyakov et al. 2018), which appears to be the poorly fixated area of the transitional cylinder and central sheath.

\section{Discussion}

Flagellated cells of larval epithelium in Haplosclerida (Amano and Hori 1996; Leys and Degnan 2002; Nakanishi et al. 2014) and Suberitida (Ereskovsky 2010) are known to be transdifferentiated during the metamorphosis and havingno continuity betweenflagellumof the 
larva and choanocytes.It is not surprising, therefore, that the kinetid structure in flagellated cells of Haliclona aquaeductus and Halichondria panicea displays a profound difference. The schemes of studied flagellar apparatusesof these species are presented in figures 11 and12.

Kinetid comparison of larvae and adults ofthe two spongesfrom different orders reveals more complex flagellar structure in larval cells. Their flagellum is strengthening by transverse (lateral arm in $H$. aquaeductus and multiple microtubules in $H$. panicea) and longitudinal (welldeveloped fibrillar rootlets) cytoskeleton. Also, in H. aquaeductustheflagellum is immersed in apical part of columnar cell which probably defends its most fragile basic part (Blum 1971; Chakrabarti 1998). Kinetid structures of choanocytes are in accordance with those of closely relatedspecies (Pozdnyakov and Karpov 2015, 2016; Pozdnyakov et al. 2017).

Trying to figure out how variable the kinetid organization is among sponge larvae and whether or not it has phylogenetic relevance within certain groups, it is necessary to compare the obtained results with the already known data.

Haplosclerid larvae had been investigated in several studies, and some information on their kinetid structure is available. According to the literature data, kinetid structure is variable within the order Haplosclerida and evenwithin the genusHaliclona, which is polyphyletic (Redmond et al. 2011).System of flagellar rootlets is apparently the most plastic element of thekinetid in these sponges.

Rootlets. The most peculiar feature found in the flagellar apparatus of H. aquaeductus, large tube fibrillar rootlets, is alsorecognizable on the photos of Amphimedonqueenslandica (LeysandDegnan2001, fig. 9c) and Haliclona (Soestella) caerulea(Hechtel, 1965)(Maldonado et al. 2003, fig. 3a-c; 5c) and clearly seen in Haliclona tubifera(George \& Wilson, 1919)(Woolacott 1993, fig. 7; WoolacottandPinto 1995, fig. 3; 10), though the kinetid scheme proposed in the last article does not reflect their three-dimensional tube organization. The layered structure of rootlets described by WoolacottandPinto(1995) has not been revealed in $H$. aquaeductus. Unlike $H$. tubifera, the rootlets of $H$. aquaeductus are multiple (up to four) and have its criss-cross cortical pattern starting just from the kinetosome. Rootlets of other haplosclerids studied look like a bunch of filaments with closelyassociated mitochondria: Haliclona sp. 1 (Nielsen 1987), Haliclona sp. 2 (AmanoandHori 1994)and Haliclona permollis(Bowerbank, 1866) (accepted name - Haliclona cinerea (Grant, 1826))(AmanoandHori 1996).

Basal footstructure also appears to be a variable morphotrait. It is quite similar insome haplosclerid larvae and presented by double (H. caeruleaand, apparently, Haliclona sp.2) or triple (A. queenslandica) foot connected with the kinetosome by bands (Amano and Hori 1994; Leys and Degnan 2001). In $H$. tubifera the foot is shown stalked, with roundish cap in 
longitudinal section (as in H. aquaeductus), but without cross sections it is not possible to identify its real shape.

Lateral arm found in $H$. aquaeductus was also reported for $H$. tubifera by Woolacott and Pinto (1995). However, it is worth to note that the arm is well-seen on cross sections but not on longitudinal ones, and this kinetid element could be missed in previous studiesdevoted to other species.

A personal discussion deserves Haliclonaindistinctadealt byStephens et al. (2013). Being clear haplosclerid according to the genetic studies (Stephens2013), this sponge has larva that differs from larvae of other haplosclerid species by several features such as lacking of spicules, ciliary tuft and unciliated posterior pole. Its adults also have an unusual for haploscleridmorphotrait: choanocyte chambers directly contact with mesohyl, which matches topoecilosclerids rather thanhaplosclerids (Langenbruchand Jones 1990). Kinetid ofboth larva and adult also does not look like characteristic of Haplosclerida. It has an axial granule, typical of several sponge lineages but not haplosclerids (Pozdnyakov et al. 2018), and pear-shape nucleus in larval cells, which was noted in Suberitida (Woolacott 1990; WoolacottandPinto 1995), Spongillida (Ivanova 1997), Poecilosclerida (WoolacottandPinto 1995), Keratosa(WoolacottandPinto 1995; Ereskovskyand Tokina 2004; UsherandEreskovsky 2005; Gonobobleva 2007; Maldonado 2009) and calcareous sponges (Borojevic 1969; Amano and Hori 1992; Gallisianand Vacelet 1992; Amano and Hori 2001; Ereskovsky and Willenz 2008; Gallisian 1983; Lannaand Klatau 2012). It is likely that the nucleus of $H$. indistincta has a connection with the kinetid, which sometimes can be definitely detected only on series sections, as well as the accessory centriole.Flagellar rootlets of $H$. indistinctalarva look like short tuft of filaments not associated with mitochondria, but adjoining the Golgi apparatus, and the kinetosome contains the axial granule. Such set of charactersresembles the kinetid in Poeciloscleridaand Suberitida (Woolacott and Pinto 1995;Uriz et al. 2001;Pozdnyakov and Karpov 2016), although the axial granule is also seen in larval cells ofHaliconasp. (Nielsen 1987). Complex of the abovementioned features prompts to pay more attention to this species and make sure that the material of morphological studies matches to that of moleculargenetic analyses.

In our study, three types of flagellated cells were detected in larvae of H. aquaeductus: 1) columnar cells, the main cell motors; 2) photosensitive tuft cells that detect light and serve as rules (Leys andDegnan 2001; Maldonado et al. 2003); 3) flask cells that are probably in charge of settlement processes and apparently fulfill a sensory function (Nakanishi et al. 2015; Mahand Leys 2017). These cell types possess distinct kinetid components (fig. 11).Differences in the kinetid structure of different cells of a sponge larva were briefly discussed in few works.Kinetid structures of anterolateral cells and long-flagellated cells of the tuft werecomparedfor $H$. 
caeruleaby Maldonado et al.(2003). The authors pointed out that central pair of microtubules of the short flagellastartmore distal than surrounding plasma membrane, while in long-flagellated tuft cellsit rises at the level of the surrounding membrane, which corresponds to the scheme observed in $H$. aquaeductus. In both sponges there is also an additional MTOC-like structure under the basal foot in tuftcells. However, unlike H. aquaeductus, in $H$. caerulea rootlets of tuft cells are more developed than in common columnar cells.In A. queenslandicakinetid structure of long posterior flagella does not appear different from that of the short lateral cilia (LeysandDegnan 2001).

Flask cells were reported to be devoid of rootlets and additional centriole in H. tubifera. They possess round nucleus and kinetosome serving as MTOC, but series sections were not investigated (Woolacott 1993). In H. aquaeductus these cells also have no rootlets, but possesses prominent MTOC of irregular shape and the centriole attached to the protrusion of the nucleus. The inconsistent position of the centriole and absence of bridges that usually connect the accessory centriole with the kinetosome allow us to doubt about its participation in the flagellar functioning.

It should be also noted that the third central microtubule in the transition zone of larval flagellum in H. caerulea (Maldonado et al. 2003; Maldonado 2004) actually can be interpreted as an element of the central sheath, which is thickened in the area of the central cylinder in H.aquaeductus(fig. $2 \mathrm{fl}$ ) and may give an appearance of an additional central tubule in this region.

Kinetid structure in Suberitida larvae is known from three species: Halichondria melanodocia, H. coerulea, Hymeniacidonheliophila(Woolacottand Pinto 1995). Its organization corresponds to the obtained scheme forHalichondria panicea and differs from the scheme of choanocyte kinetid proposed for Suberitida and Poecilosclerida (PozdnyakovandKarpov 2016)primarily by the presence of the permanentadditional centriole situated on the rootlets, quite far from the kinetosome. It should be noted that poecilosclerid larvae studied for today also have the accessory centriole (Mycale ceciliaLaubenfels, 1936 (Woolacottand Pinto 1995), Crambecrambe(Schmidt, 1862) (Uriz et al. 2001),HymedesmiairregularisLundbeck, 1910 (Sokolova et al. in preparation)).

Thus, one can observea significant diversity of sponge larval kinetid within the only one order of demosponges, Haplosclerida. This seems not surprising because this order is really large; it is considered as the sister clade with the rest of Heteroscleromorpha, the group which includes the majority of Demospongiae species (Morrow and Cardenas 2015). Given the relative consistency of the flagellar apparatus in adult sponges (Pozdnyakov et al. 2017), it is of interest to reveal the 
patterns underlying such a diversity. Choanocytes of different demosponges function in the same way, while flagella of larval locomotory cells can realize diverse moving patterns (Maldonado 2006). It can be supposed that the kinetid structure correlates with locomotion patterns of larvae: the more complex the kinetid is, the mobile and agile larva is. However, larvae of Haliclonaaquaeductus possess kinetid structure that sharesfew features with larvae ofthe dictyoceratidIrciniaoros(Schmidt, 1864)(EreskovskyandTokina 2004) having similar body plan (tufted parenchymella with bare posterior pole).

One should note that it is the high-speed maneuverable larva of $H$. aquaeductus that possess the stout rootlets, which serve actually as the pipelines leading to mitochondria and obviously effective machinery for energy transformation/transport/accumulation and usage. Probably, rootlet reduction in the cells of tuft reflects the low energy requirement of these cells (serving rather as a rule than as a motor). But the reverse trend in H. caerulea(Maldonado et al. 2003) does not correspond to this assumption. The biochemical processes taking place in the tube rootlets are a relevant theme for prospective studies.

At the same time, other sponge lineages display some consistency in larval kinetid structure, as can be inferred for today. Particularly, studied calcareous sponges (Borojevic 1969; Amano and Hori 1992; Gallisianand Vacelet 1992; Amano and Hori 2001; Ereskovsky and Willenz 2008; Gallisian 1983; LannaandKlatau 2012)as well as homoscleromorphs (Boury-Esnault et al.2003, Maldonado andRiesgo 2008)and eumetazoans (Nielsen 1987) possess apical nuclei linked to the kinetid in larval ciliated cells, accessory centriole and striated rootlets. Kinetids of Poecilosclerida Crambecrambe(Uriz et al. 2001), Mycale cecilia (Woolacottand Pinto 1995), Hamigerahamigera(Schmidt, 1862)(Boury-Esnault 1987)and Hymedesmiairregularis(Sokolova et al. in preparation) comprise kinetosome which bears laminar rootlets and, apparently, accessory centriole (seen in H. irregularis, C. crambe, $M$. cecilia). The abovementioned kinetids of Suberitida (Halichondria melanodocia, H. coerulea, Hymeniacidonheliophila(Woolacottand Pinto 1995)) are also similar within the group. Spicule-less spongesHalisarca dujardiniJohnston, 1842 (Gonobobleva2007), Irciniaoros(Ereskovsky and Tokina 2004), Aplysina aerophoba(Nardo, 1833)(Maldonado 2009), Aplysilla sp. (Woolacottand Pinto 1995), CacospongiamolliorSchmidt, 1862(Uriz et al. 2008), ChondrillaaustraliensisCarter, 1873(Usher and Ereskovsky 2005), also possess the kinetidquite similar to that in calcareous and homoscleromorph sponges iterating the situation observed in choanocytes (Pozdnyakov et al. 2017); though unlike Calcarea larval kinetid of these sponges lack striated rootlets, they are shown present in embryos of $H$. dujardini(Gonobobleva 2007). It should be emphasized that Verongimorpha representatives were shown to possess the apical nucleus associated with the kinetid (A. aerophoba, H. dujardini, C. australiensis), while studied Keratosa have the basal nucleus placed far from the flagellum (C. molior.I. oros, Aplysilla sp., 
Pleraplysillaspinifera(unpubl. data)). However,Aplysillasp. (WoolacottandPinto 1995), is out of that line as its kinetid has MTOC shaped as lateral arms (as in some Haliclona representatives) and laminar rootlets (as in Poecilosclerida representatives), and Halichondria mooreiBergquist, 1961 (Evans 1977) possesses the basal nucleus. Also, large portion of illustrations have no enough resolution for resolving of fine structures and no series sections and scarce cross sections that allow us to detect precisely the configuration of the flagellar apparatus. Thus, any conclusions about phylogenetic signal of kinetid components should be made carefully and until more sponge larvae are studied, this issue awaits elucidation.

\section{Acknowledgements}

The research was supported by the Russian Foundation for Basic Research (projects no. 17-30450015 and 18-04-01314). We thank Research Resource Center for Microscopy at Zoological Institute of Russian Academy of Sciences and Research Resource Center for Molecular and Cell Technologies (RRC MCT) at St. Petersburg State University for access to the EM facilities.

Conflict of Interest: The authors declare that they have no conflict of interest.

\section{References}

1. Amano S, Hori I (1996) Transdifferentiation of larval flagellated cells to choanocytes in the metamorphosis of the demosponge Haliclona permollis. Biol Bull 190:161-172

2. Amano S, Hori I (1994) Metamorphosis of a demosponge I. Cells and structure of swimming larva. InvertebrReprod Dev 25:193-204. doi: $10.1080 / 07924259.1994 .9672386$

3. Amano S, Hori I (2001) Metamorphosis of coeloblastula performed by multipotential larval flagellated cells in the calcareous sponge Leucosolenia laxa. Biol Bull 200:20-32

4. Amano S, Hori I (1992) Metamorphosis of calcareous sponges I. Ultrastructure of freeswimming larvae. InvertebrReprod Dev 21:81-90. doi: 10.1080/07924259.1992.9672223

5. Andersen RA, Barr DJS, Lynn DH, et al (1991) Terminology and nomenclature of the cytoskeletal elements with the flagellar/ciliary apparatus in protists. Protoplasma 164:18. doi: 10.1007/BF01320809

6. Barr DJS (2001)Chytridiomycota. In: McLaughlin DJ, McLaughlinEG, Lemke PA (eds) The Mycota VII, Part A: Systematicsand Evolution. Springer-Verlag, Berlin, pp.93-112

7. Blum JJ (1971) Existence of a breaking point in cilia and flagella. J TheorBiol 22:257263

8. Borojevic R (1969) Étude du développement et de la différenciation cellulaire d'éponges calcaires calcinèennes (genres Clathrina et Ascandra). Ann Embryol Morph 2:15-36 
9. Boury-Esnault N (1976) Ultrastructure de la larve parenchymella d'Hamigerahamigera(Schmidt) (Démosponge, Poecilosclerida). Origine des cellules grises. CahBiol Mar 17:9-20

10. Boury-Esnault N, Ereskovsky A, Bezac C, Tokina D (2003) Larval development in the Homoscleromorpha (Porifera, Demospongiae). InvertebrBiol 122:187-202

11. Chakrabarti A, Schatten H, Mitchell KD, et al (1998) Chloral hydrate alters the organization of the ciliary basal apparatus and cell organelles in sea urchin embryos. Cell Tissue Res 293:453-462

12. Ereskovsky AV (2010) The comparative embryology of sponges. Springer Science and Business Media, London, New York

13. Ereskovsky AV, Tokina DB (2004) Morphology and fine structure of the swimming larvae of Irciniaoros (Porifera, Demospongiae, Dictyoceratida). InvertebrReprod Dev 45:137-150. doi: 10.1080/07924259.2004.9652583

14. Ereskovsky AV, Willenz P (2008) Larval development in Guanchaarnesenae (Porifera, Calcispongiae, Calcinea). Zoomorhology 127:175-187. doi: 10.1007/s00435-008-0061-9

15. Evans CW (1977) The ultastructure of larvae from the marine sponge Halichondria moorei Bergquist (Porifera, Demospongiae). CahBiol Mar 13:427-433

16. Gallissian M-F (1983) Etude ultrastructurale du developpement embryonnaire chez Grantia compressa F. (Porifera, Calcarea). Arch d'AnatomieMicrosc 72:59-75

17. Gallissian M-F, Vacelet J (1992) Ultrastructure of the oocyte and embryo of the calcified sponge, Petrobionamassiliana (Porifera, Calcarea). Zoomorphology 112:133-141

18. Gonobobleva EL (2007) Basal apparatus formation in external flagellated cells of Halisarca dujardini larvae (Demospongiae: Halisarcida) in the course of embryonic development. In: Porifera research: biodiversity, innovation and sustanability. pp 345351

19. Ivanova L (1997) New data about morphology and metamorphosis of the spongillid larvae (Porifera, Spongillidae). 1. Morphology of the free-swimming larvae. Berliner geowissAbh 20:55-71

20. Karpov SA (2000) Flagellatephylogeny: ultrastructural approach. In: Leadbeater BS, Green JC (eds) The Flagellates: Unity, Diversity and Evolution. Taylor and Francis, London, pp.336-360.

21. Langenbruch PF, Jones CW (1990) Body structure of marine sponges. VI Choanocyte chamber structure in the Haplosclerida (Porifera, Demospongiae) and its relevance to the phylogenesis of the group. J Morphol 204:1-8. 
22. Lanna E, Klautau M (2012) Embryogenesis and larval ultrastructure in Paraleucilla magna (Calcarea, Calcaronea), with remarks on the epilarvaltrophocyte epithelium 'placental membrane'). Zoomorphology 131:277-292. doi: 10.1007/s00435-012-0160-5

23. Leys SP, Degnan BM (2001) Cytological basis of photoresponsive behavior in a sponge larva. Biol Bull 201:323-338

24. Leys SP, Degnan BM (2002) Embryogenesis and metamorphosis in a haplosclerid demosponge: gastrulation and transdifferentiation of larval ciliated cells to choanocytes. InvertebrBiol 121:171-189

25. Mah JL, Leys SP (2017) Think like a sponge: the genetic signal of sensory cells in sponges. Dev Biol 431:93-100. doi: 10.1016/j.ydbio.2017.06.012

26. Maldonado M, Durfort M, McCarthy DA, Young CM (2003) The cellular basis of photobehavior in the tufted parenchymella larva of demosponges. Mar Biol 143:427-441. doi: $10.1007 / \mathrm{s} 00227-003-1100-1$

27. Maldonado M (2006) The ecology of the sponge larva. Can J Zool 84:175-194. doi: 10.1139/Z05-177

28. Maldonado M (2009) Embryonic development of verongid demosponges supports the independent acquisition of spongin skeletons as an alternative to the siliceous skeleton. Biol J Linn Soc 97:427-447. doi: 10.1111/j.1095-8312.2009.01202.x

29. Maldonado M (2004) Choanoflagellates, choanocytes, and animal multicellularity. InvertebrBiol 123:1-22

30. Maldonado M, Riesgo A (2008) Reproductive output in a Mediterranean population of the homosclerophoridCorticium candelabrum (Porifera, Demospongiae), with notes on the ultrastructure and behavior of the larva. Mar Ecol 29:298-316. doi: 10.1111/j.14390485.2008.00244.x

31. Moestrup Ø (1982) Flagellar structure in algae: a review, with new observations particularly on the Chrysophyceae, Phaeophyceae (Fucophyceae), Euglenophyceae, and Reckertia. Phycologia 21:427-528.

32. Moestrup Ø(2000). The flagellate cytoskeleton: introduction of ageneral terminology for microtubular roots in protists. In: Leadbeater BS, Green JC, (eds). The Flagellates: Unity, Diversity and Evolution. Taylor and Francis, London, pp.69-94.

33. Morrow C, Cárdenas P (2015) Proposal for a revised classification of the Demospongiae (Porifera). Front Zool 12:.doi: 10.1186/s12983-015-0099-8

34. Nakanishi N, Sogabe S, Degnan BM (2014) Evolutionary origin of gastrulation: insights from sponge development. BMC Biol 12:1-9. doi: 10.1186/1741-7007-12-26 
35. Nakanishi N, Stoupin D, Degnan SM, Degnan BM (2015) Integrative and comparative biology sensory flask cells in sponge larvae regulate metamorphosis via calcium signaling. Integr Comp Biol 55:1018-1027. doi: 10.1093/icb/icv014

36. Nielsen C (1987) Structure and function of metazoan ciliary bands and their phylogenetic significance. ActaZool 68:205-262. doi: 10.1111/j.1463-6395.1987.tb00892.x

37. Pozdnyakov IR, Karpov SA (2015) Structure of choanocyte's kinetid in sponge Haliclona sp.(Demospongiae, Haplosclerida) and its implication for taxonomy and phylogeny of Demospongiae. ZoolZhurnal 94:17-25. doi: 10.7868/S0044513415010122

38. Pozdnyakov IR, Karpov SA (2013) Flagellar apparatus structure of choanocyte in Sycon sp. and its significance for phylogeny of Porifera. Zoomorhology 132:351-357. doi: $10.1007 / \mathrm{s} 00435-013-0193-4$

39. Pozdnyakov IR, Karpov SA (2016) Kinetid structure in choanocytes of sponges (Heteroscleromorpha): toward the ancestral kinetid of Demospongiae. J Morphol 277:925-934. doi: 10.1002/jmor.20546

40. Pozdnyakov IR, Sokolova AM, Ereskovsky AV, Karpov SA (2017) Kinetid structure of choanoflagellates and choanocytes of sponges does not support their close relationship. Protistology 11:248-264. doi: 10.21685/1680-0826-2017-11-4-6

41. Pozdnyakov IR, Sokolova AM, Ereskovsky AV, Karpov SA (2018) Kinetid structure in sponge choanocytes of Spongillida in the light of evolutionary relationships within Demospongiae. Zool J Linn Soc XX:1-18. doi: 10.1093/zoolinnean/zlx109/4905843

42. Redmond NE, Raleigh J, Soest RWM Van, et al (2011) Phylogenetic relationships of the marine Haplosclerida (phylum Porifera) employing ribosomal (28S rRNA) and mitochondrial (cox1, nad1) gene sequence data. PLoS One 6:e24344. doi: 10.1371/journal.pone.0024344

43. Simion P, Philippe H, Baurain D, Jager M, et al (2017) A large and consistent phylogenomic dataset supports sponges as the sister group to all other animals. Current Biology, 27(7): 958-967. https://doi.org/10.1016/j.cub.2017.02.031

44. Stephens K (2013) Insights into the evolution and development of Haliclona indistincta (Porifera, Haplosclerida)Dissertation, National University of Ireland, Galway

45. Stephens KM, Ereskovsky AV, Lalor P, Mccormack GP (2013) Ultrastructure of the ciliated cells of the free-swimming larva, and sessile stages, of the marine sponge Haliclona indistincta (Demospongiae: Haplosclerida). J Exp Mar Bio Ecol 274:12631276. doi: 10.1002/jmor.20177

46. Uriz MJ, Turon X, Becerro MA (2001) Morphology and ultrastructure of the swimming larvae of Crambecrambe (Demospongiae, Poecilosclerida). InvertebrBiol 120:295-307 
47. Uriz MJ, Turon X, Mariani S (2008) Ultrastructure and dispersal potential of sponge larvae: tufted versus evenly ciliated parenchymellae. 29:280-297. doi: 10.1111/j.14390485.2008.00229.x

48. Usher KM, Ereskovsky AV (2005) Larval development, ultrastructure and metamorphosis in Chondrillaaustraliensis Carter, 1873 (Demospongiae, Chondrosida, Chondrillidae). InvertebrReprod Dev 47:51-62. doi: 10.1080/07924259.2005.9652146

49. Woollacott RM (1990) Structure and swimming behavior of the larva of Halichondria melanadocia (Porifera: Demospongiae). J Morphol 205:135-145

50. Woollacott RM (1993) Structure and swimming behavior of the larva of Haliclona tubifera (Porifera: Demospongiae). J Morphol 218:301-321

51. Woollacott RM, Pinto RL (1995) Flagellar basal apparatus and its utility in phylogenetic analyses of the Porifera. J Morphol 226:247-265

52. Yubuki N, Leander BS (2013) Evolution of microtubule organizing centers across the tree of eukaryotes. The Plant Journal 75:230-244.

\section{Figure legends}

Fig. 1 Larval stage of Haliclona aquaeductus. a - generalview of the larva (SEM), b - tuft consisting of the compound cilia (SEM), c - generalview of the anterolateral columnar cells (SEM), d - longitudinal section through the anterolateral columnar cells. Abbreviations: SC short cilia, $l p c$ - long posterior cilia, $p p$ - posterior pole, $c c$ - compound cilia, $f l-$ flagellum, $n-$ nucleus. Scale bars: $\mathrm{a}-80 \mu \mathrm{m}, \mathrm{b}-2 \mu \mathrm{m}, \mathrm{c}-5 \mu \mathrm{m}, \mathrm{d}-1.5 \mu \mathrm{m}$

Fig. 2 Distal part of the kinetid in Haliclonaaquaeductus larval cells. a - transversalsection at the level of the basal foot, b-h - serial sections of the same cell. fl - section of another cell. Abbreviations: $b f$ - basal foot, $s t$ - stalks of the foot, $l a$ - lateral arm, $t f$ - transitional fibers, $m c t-$ microtubules, $a p$ - anchoring points, $p d$ - peripheral doublet, $\mathrm{cm}$ - central microtubules, sh sheath, $t c$ - transitional cylinder. Scale bar: $0.2 \mu \mathrm{m}$

Fig. 3Details of the kinetid structure in antero-lateral columnar cells of Haliclona aquaeductuslarva. a, b - longitudinal sections through the kinetosome, c-e - longitudinal sections through the rootlets, $\mathrm{f}-\mathrm{g}$ - cross sections of the rootletssurrounded by mitochondria (arrows indicate the rootlets). Abbreviations: $\mathrm{cm}$ - central microtubules, tc - transitional cylinder, $b f$ - basal foot,st -stalks of the foot, $f l$ - flagellum, $k$ - kinetosome, $t p$ - transverse plate, mct- microtubules, rtl - rootlets, mtch - mitochondrion, rtl (ep) - external part of rootlets, rtl (ip) - internal part of rootlets, of - oblique fibers, ap - anchoring points. Scale bars: a-g - $0.5 \mu \mathrm{m}$, $\mathrm{c}-0.25 \mu \mathrm{m}$.

Fig. 4Tuft cells of Haliclonaaquaeductus and their kinetid. a - common view of the cells, b-f details of the kinetid structure. Abbreviations: $c c$ - compound cilia, $t c-$ transitional cylinder, $g l$ 
- glycocalyx, cm - central microtubules, MTOC - microtubule organizing center,mtch mitochondria, $t p$ - transverse plate, $r t l$ - rootlet. Scale bars: a $-3 \mu \mathrm{m}, \mathrm{b}-\mathrm{h}-0.5 \mu \mathrm{m}$

Fig. 5Flask cells of Haliclona aquaeductus and their kinetid. a, b - common view of the cells, c - kinetid appearance, d-h - serial longitudinal sections of the same cell. Abbreviations: fl flagellum, $n$ - nucleus, mtch - mitochondria, $a c$ - accessory centriole, $c m-$ central microtubules, $m c t-$ microtubules, $M T O C$ - microtubule organizing center, $k$ - kinetosome. Scale bars: $\mathrm{a}, \mathrm{b}-1 \mu \mathrm{m}, \mathrm{c}, \mathrm{d}-0.5 \mu \mathrm{m}$

Fig. 6Flagellated cells of adult Haliclona aquaeductus. a -choanocyte chamber, b - choanocyte. Abbreviations: fl- flagellum, $m c v-$ microvilli, $n$ - nucleus. Scale bars: $\mathrm{a}-10 \mu \mathrm{m}, \mathrm{b}-1 \mu \mathrm{m}$

Fig. 7 Details of the choanocyte kinetid of Haliclona aquaeductus. a, b - longitudinal sections through the kinetosome, $\mathrm{c}-$ cross section of the apical part of choanocyte, $\mathrm{d}-$ seral cross sections of through the kinetid of the same cell, e - cross section trough the kinetosome of another cell. Abbreviations: $t f$ - transitional fiber, $t p$ - transverse plate, $m c t$ - microtubules, $G a-$ Golgi apparatus, $m c v$ - microvilli,pd - peripheral doublet of microtubules. Scale bars: a, b - 0.25 $\mu \mathrm{m}, \mathrm{c}-1 \mu \mathrm{m}, \mathrm{d}, \mathrm{e}-0.2 \mu \mathrm{m}$

Fig. 8Larva of Halichondria panicea.a - common view of larva (SEM), b - surface of larva (SEM), c - longitudinal section of flagellated cell.Abbreviations: $f l$ - flagellum, $n$ - nucleus, $n u-$ nucleolus. Scale bars: $\mathrm{a}-100 \mu \mathrm{m}, \mathrm{b}-2 \mu \mathrm{m}, \mathrm{c}-1 \mu \mathrm{m}$.

Fig. 9 Details of kinetid structure in larva of Halichondria panicea. a, b - longitudinal sections through the kinetosome, $\mathrm{c}$ - cross section at the level of basal foot, $\mathrm{d}$ - cross section of a cell at the level of the Golgi apparatus. Abbreviations: eg - excretory granule, ag - axial granule, $b f-$ basal foot, mct- microtubules, $r t l$ - roolets, $G a$ - Golgi apparatus, $n$ - nucleus, $k$ - kinetosome, $\mathrm{cm}$ - central microtubules, $t c-$ transitional cylinder, $a c$ - accessory centriole, mtch mitochondria. Scale bars: $0.5 \mu \mathrm{m}$

Fig. 10 Choanocytes of the adult Halichondria panicea. a - choanocyte chamber, b-d apical part of the three choanocytes. Abbreviations: $m c v-$ microvilli, $f l-$ flagellum, $k$ - kinetosome, $G a-$ Golgi apparatus, $n$ - nucleus, $b f$ - basal foot,st- satellite, $t f$ - transitional fiber, $a g$ - axial granule, $r t$ - rootlets. Scale bar: $\mathrm{a}-2 \mu \mathrm{m}, \mathrm{b}-\mathrm{d}-0.5 \mu \mathrm{m}$

Fig. 11 Scheme of kinetid structures of Haliclona aquaeductus. a-b - antero-lateral columnar cells at longitudinal (a) and transversal(b) sections (lateral arm is not shown on the longitudinal section), c - flask cell, d - tuft cell, e - choanocyte. Abbreviations: $\mathrm{cm}$ - central microtubules,sh- sheath, $t c-$ transitional cylinder, $t p-$ transverse plate, $b f$ - basal foot, $m c t-$ microtubules, $r t l$ - rootlets, $r t$ (ip) - rootlet (internal part), rtl (ep) - rootlet (external part), $k$ kinetosome, mtch - mitochondria, MTOC - microtubule organizing center, $a c$ - accessory centriole, $n$ - nucleus, $G a$ - Golgi apparatus, $m c v$ - microvilli 
Fig. 12 Scheme of the kinetid found in flagellated cells of Halichondria panicea. Abbreviations: $n$ - nucleus, $n u$ - nucleolus 


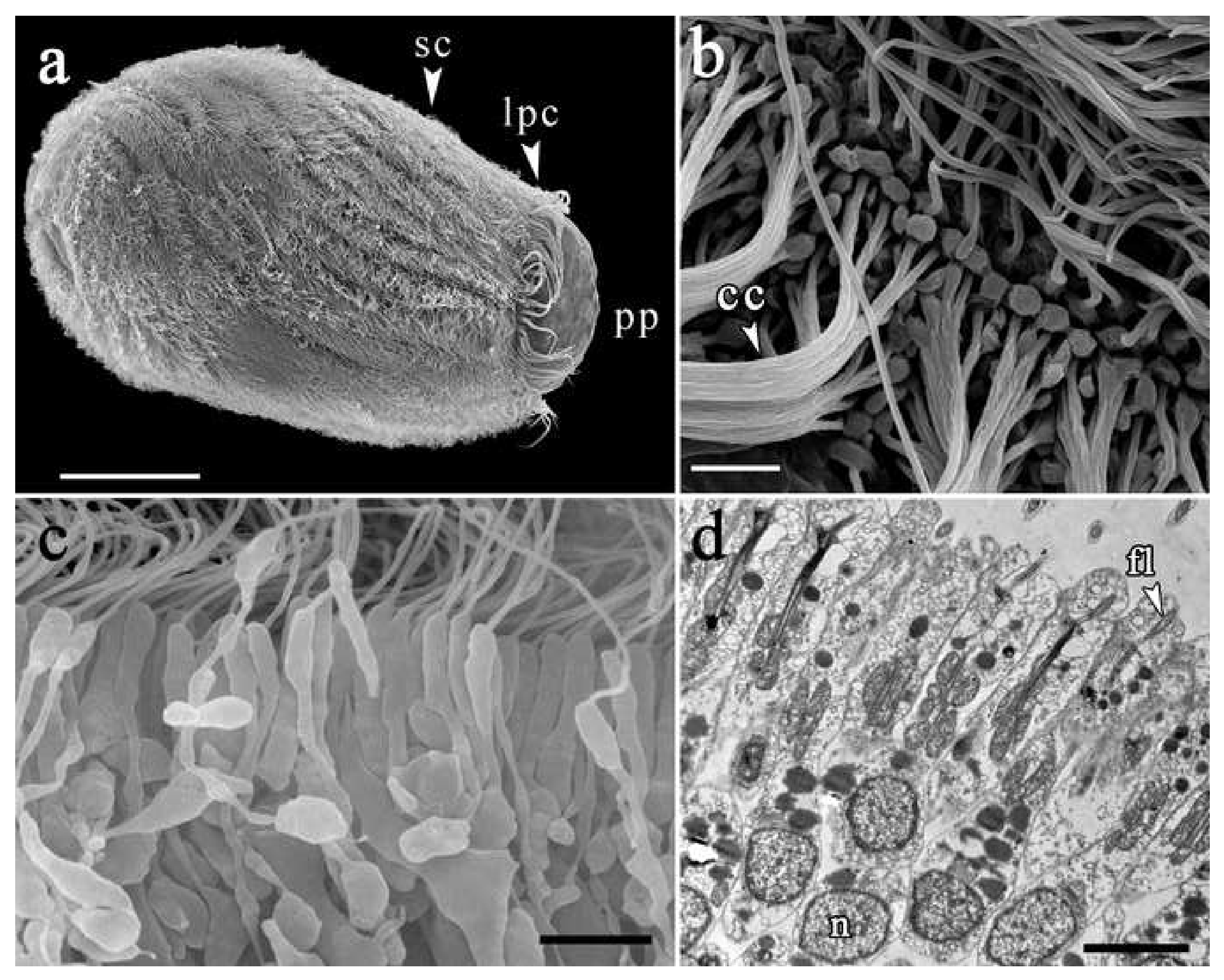




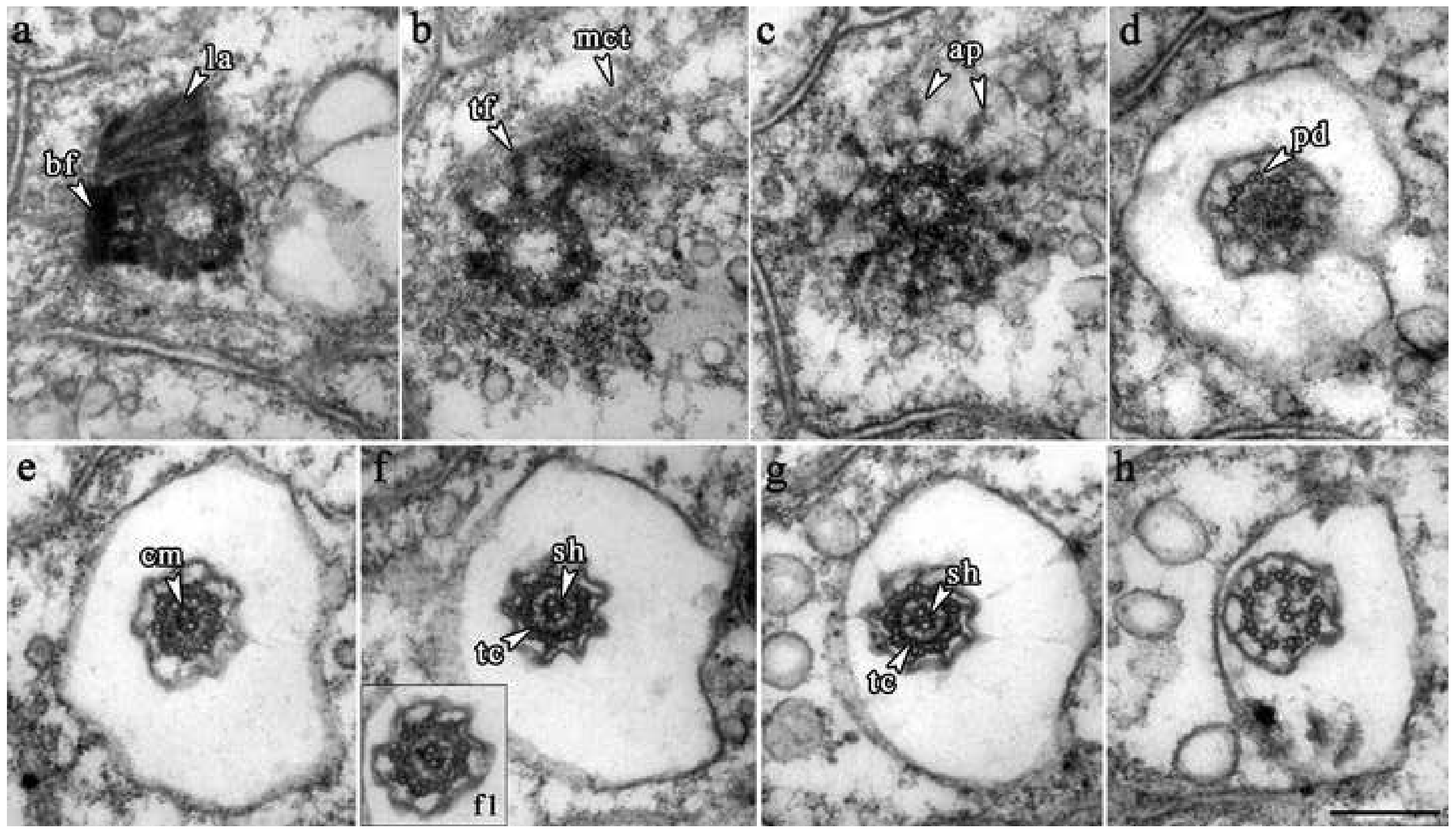




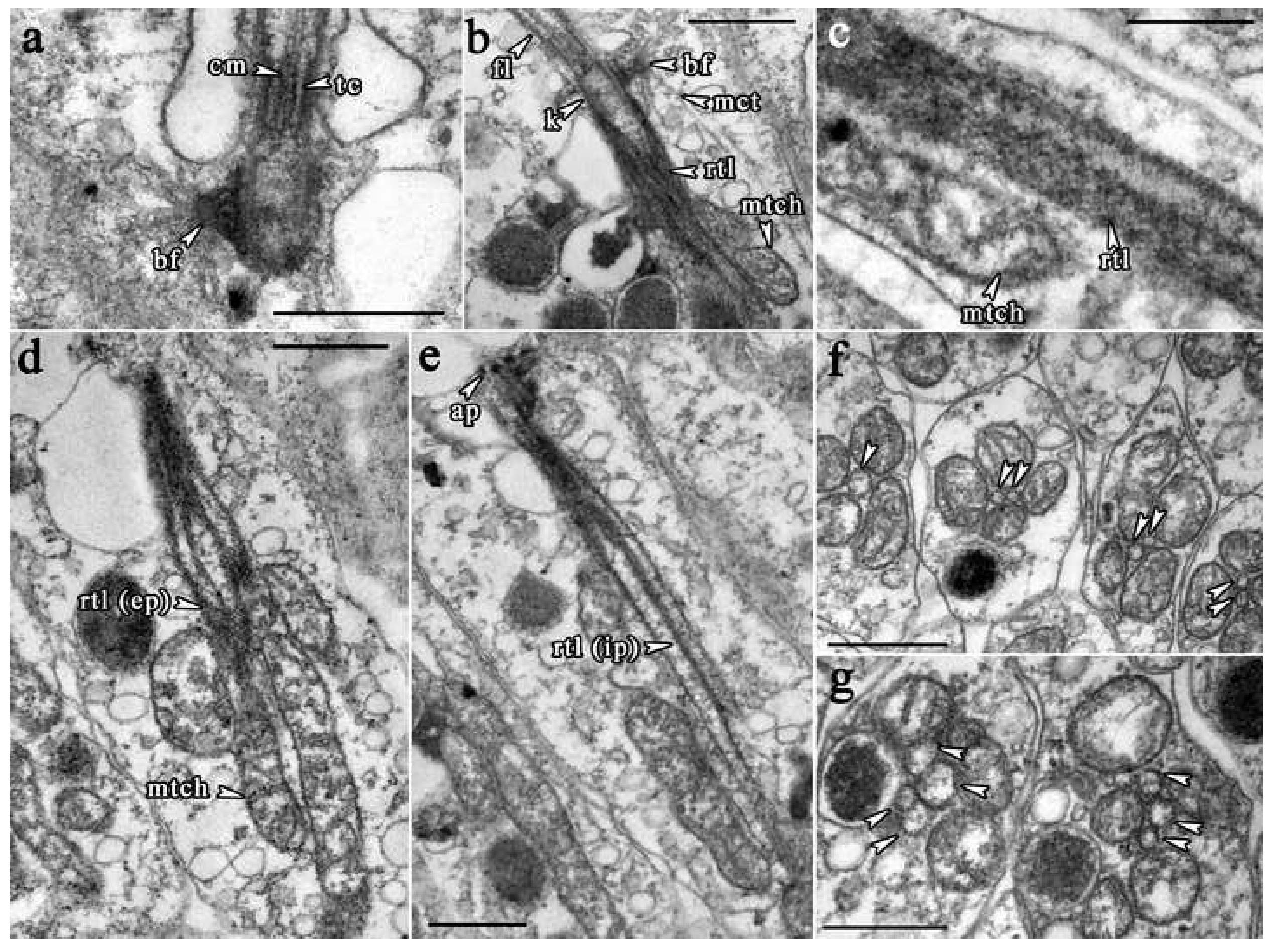




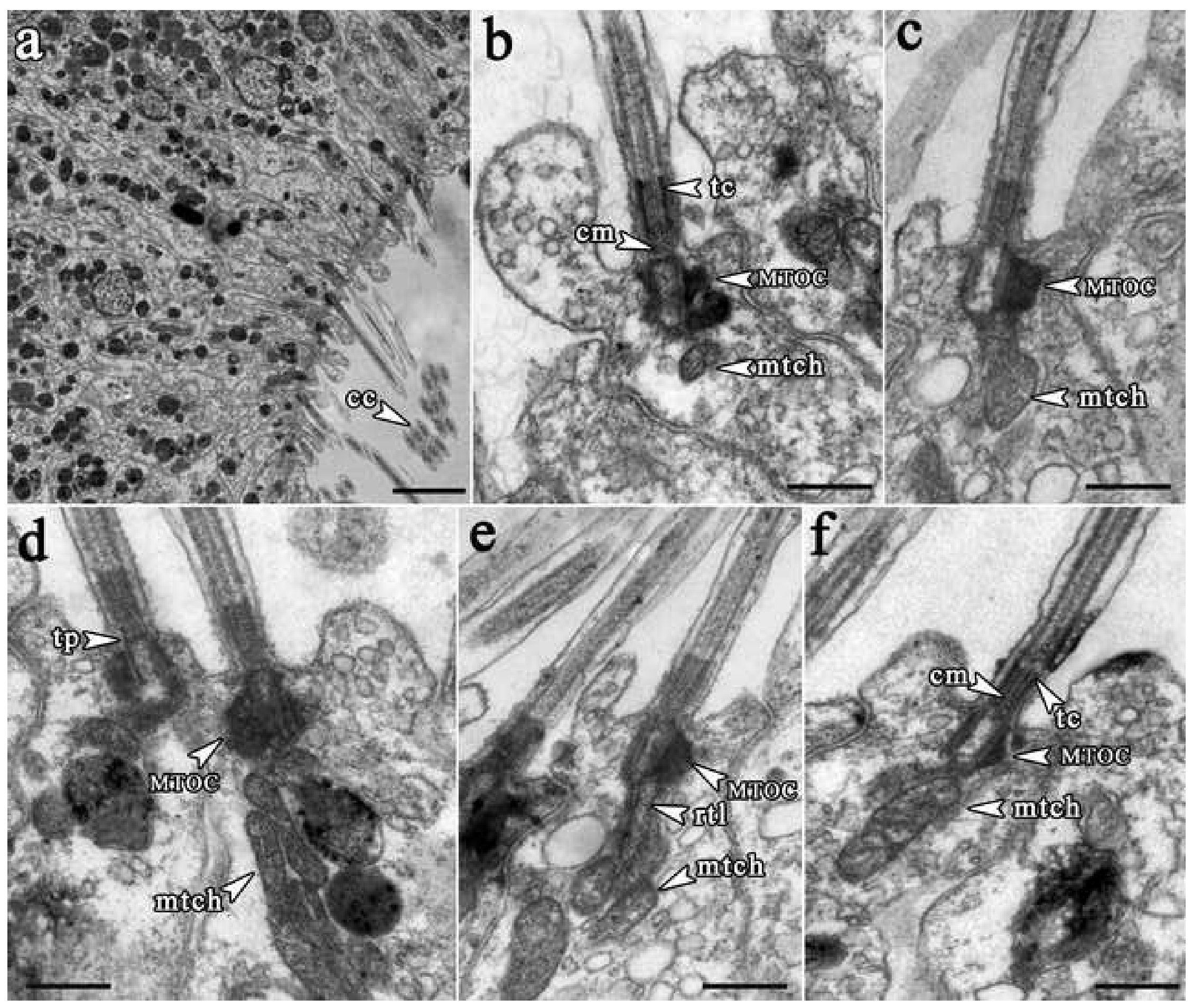




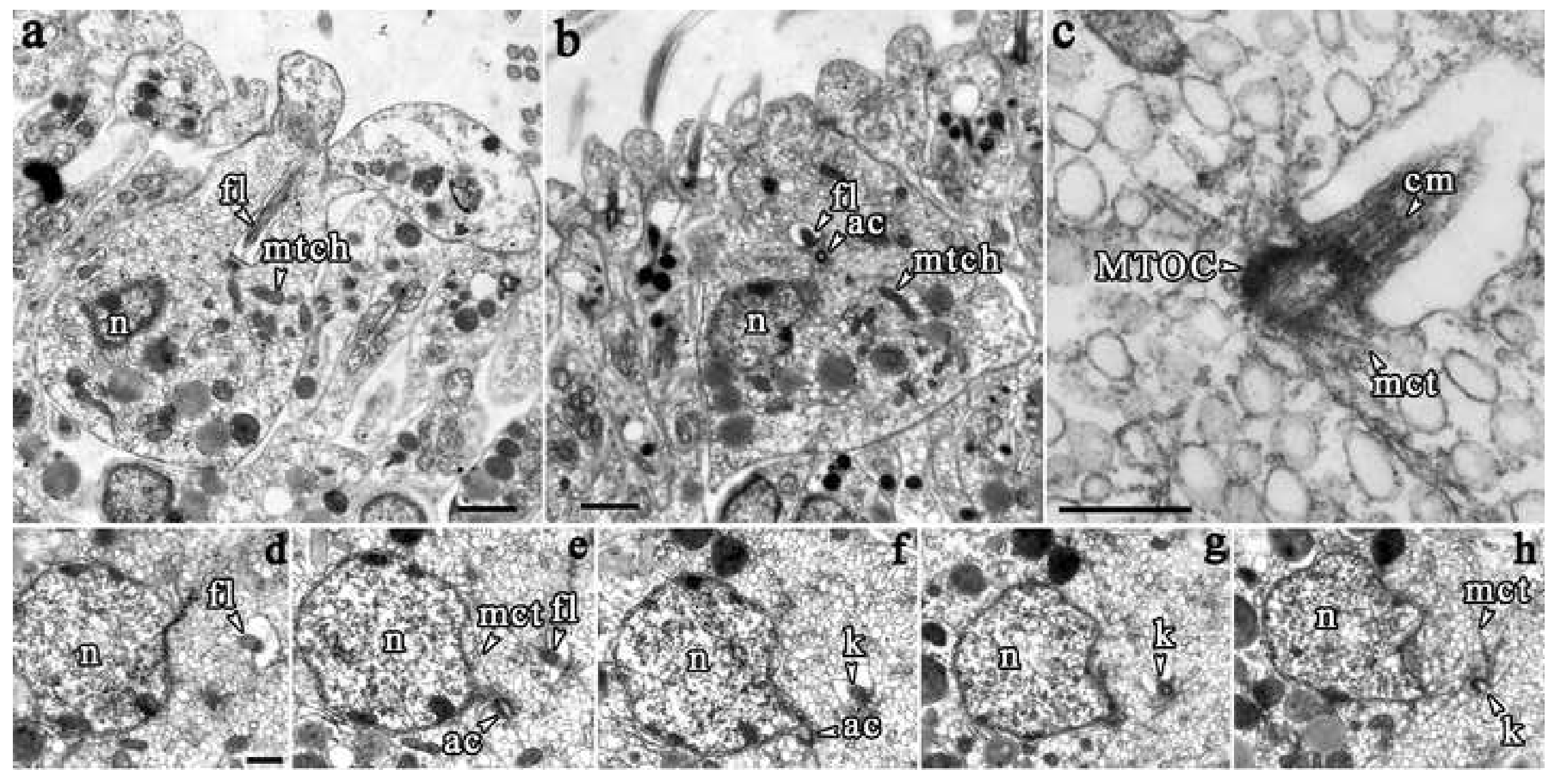




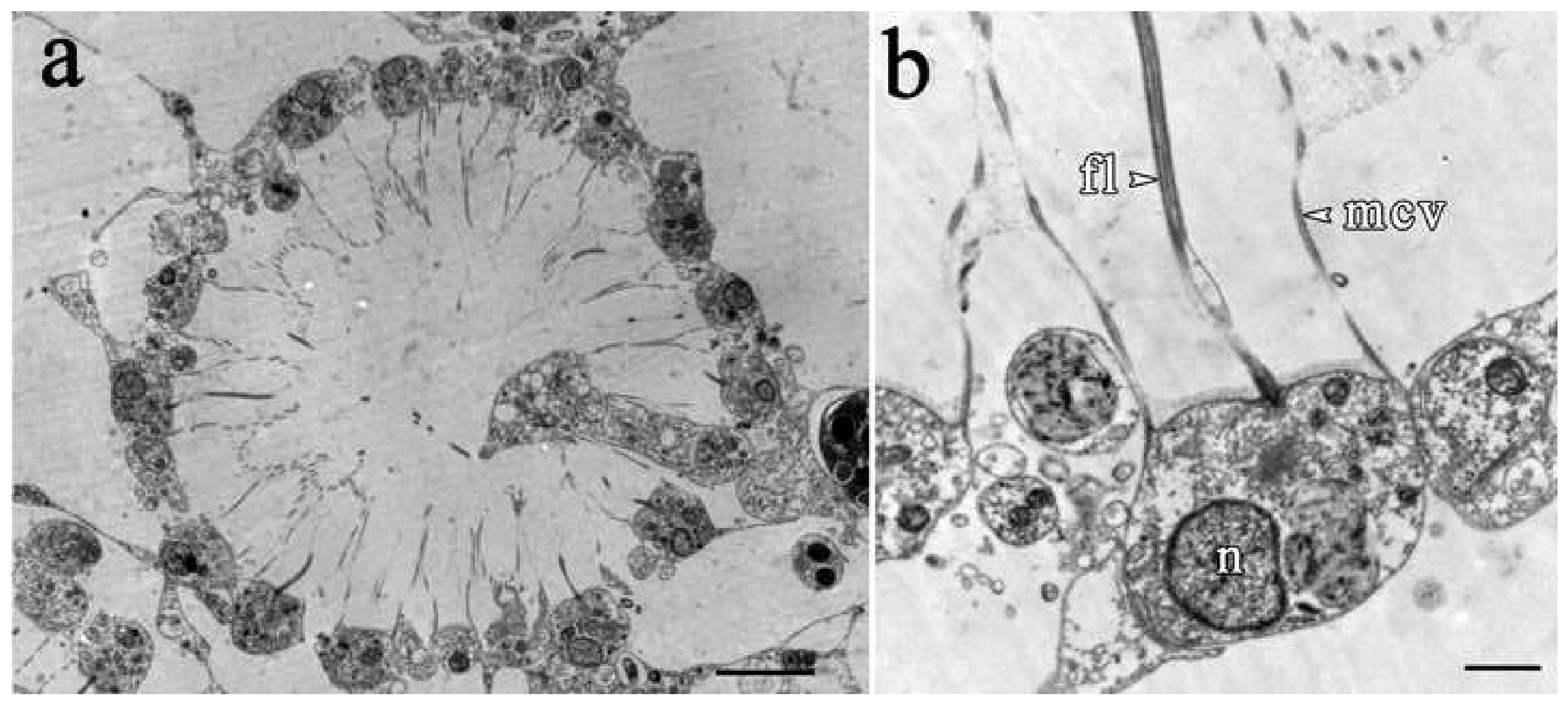




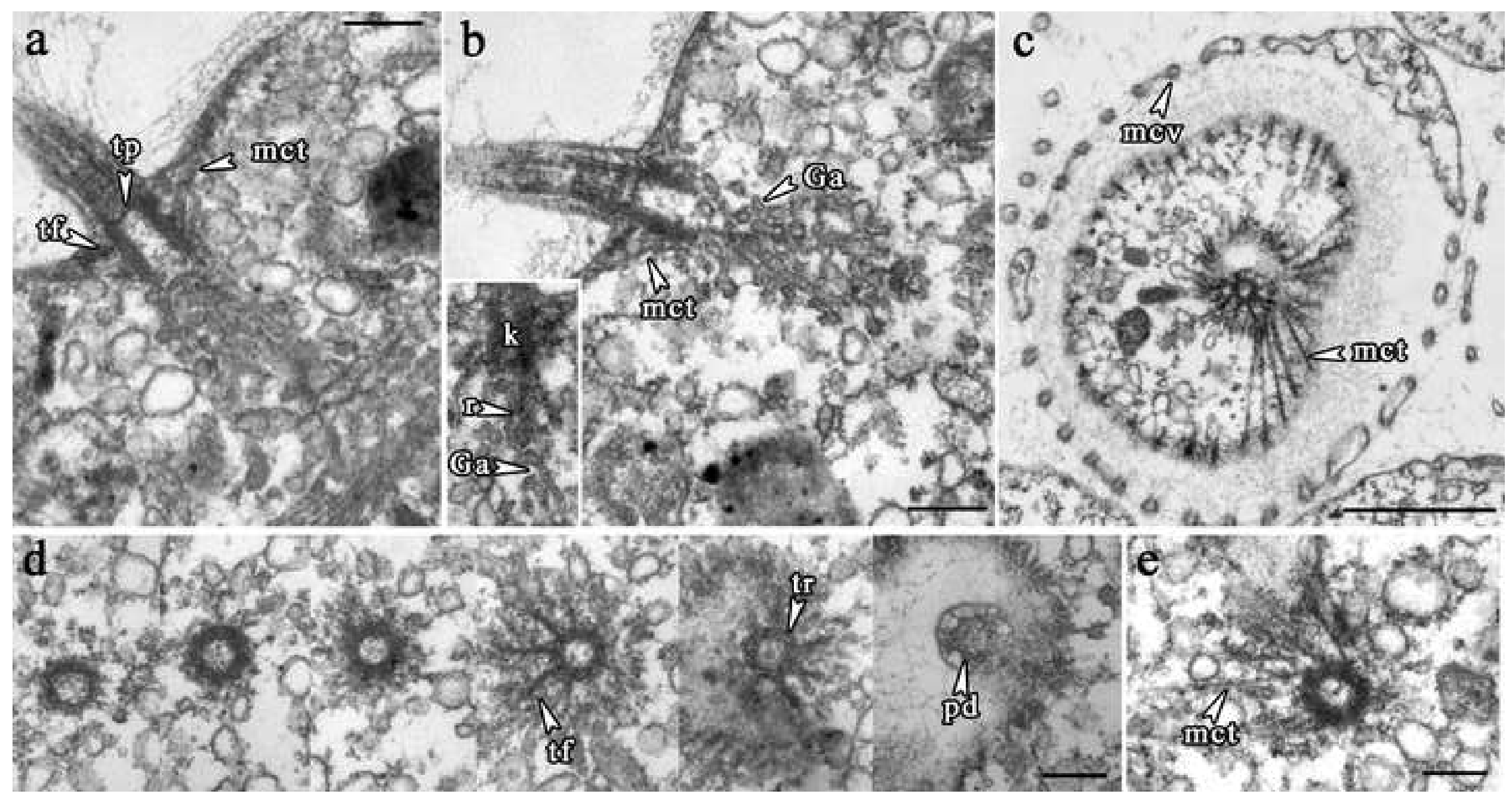



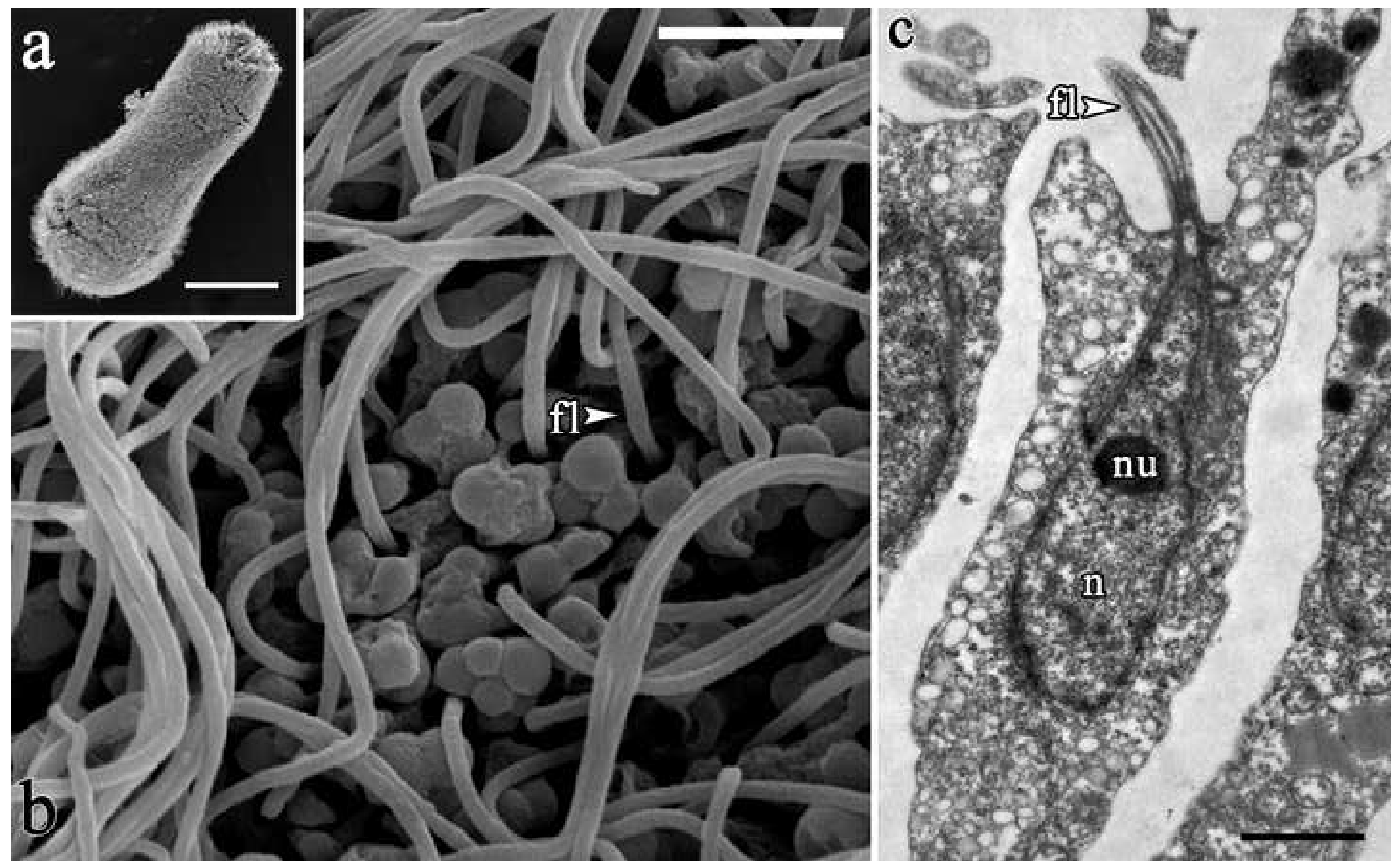


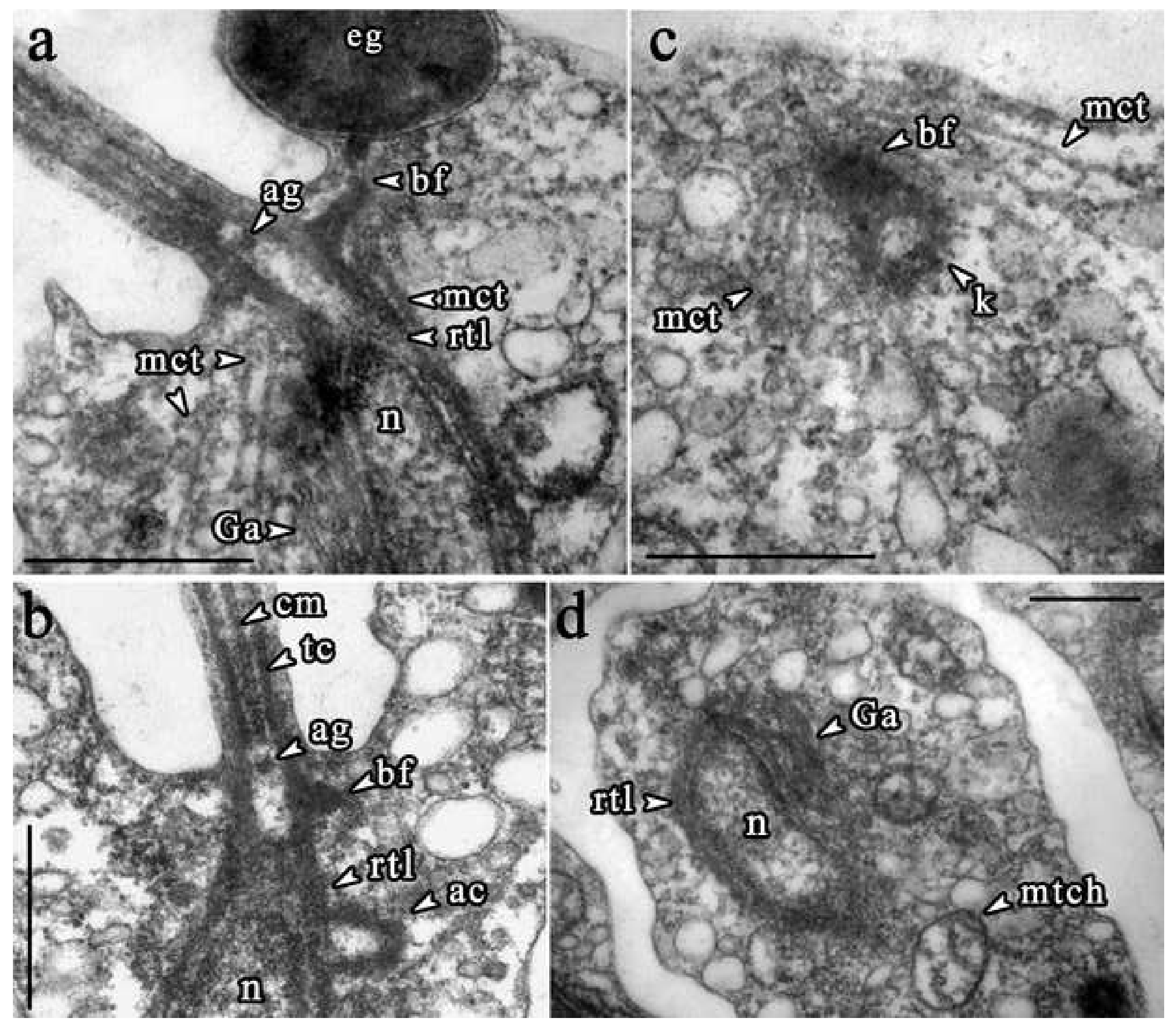




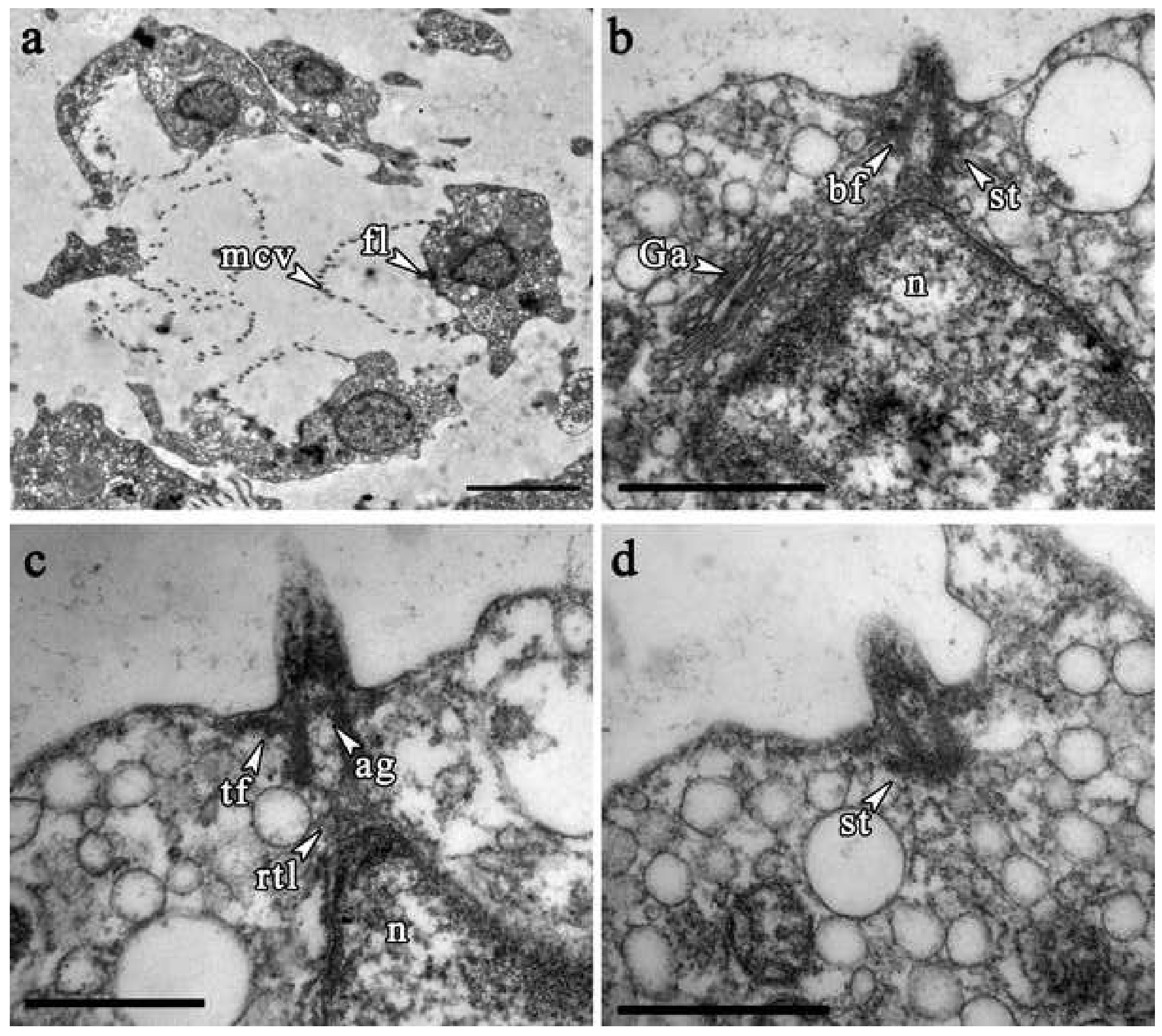


Click here to download Figure fig 11.tif $\stackrel{ \pm}{ }$

a
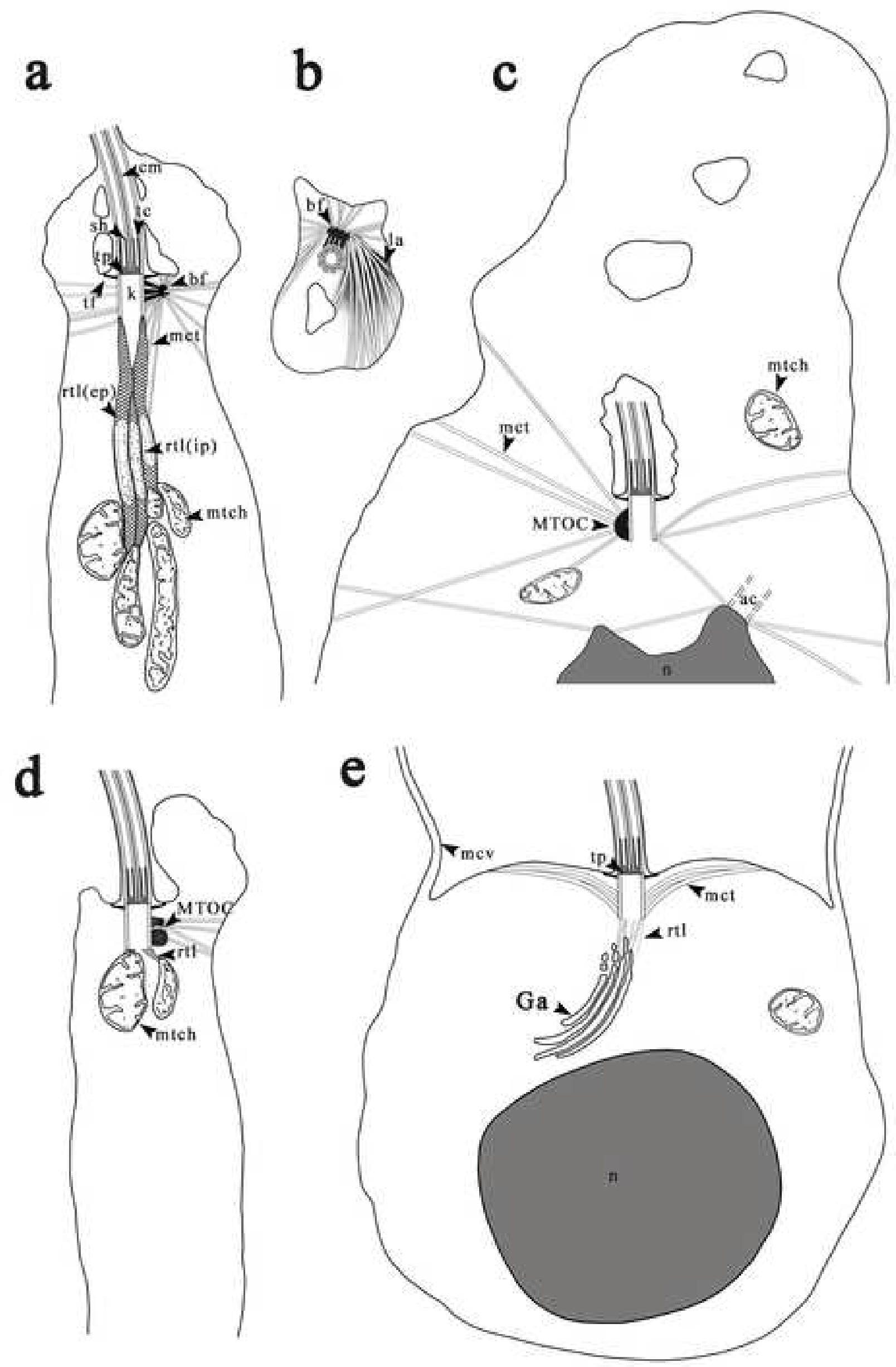


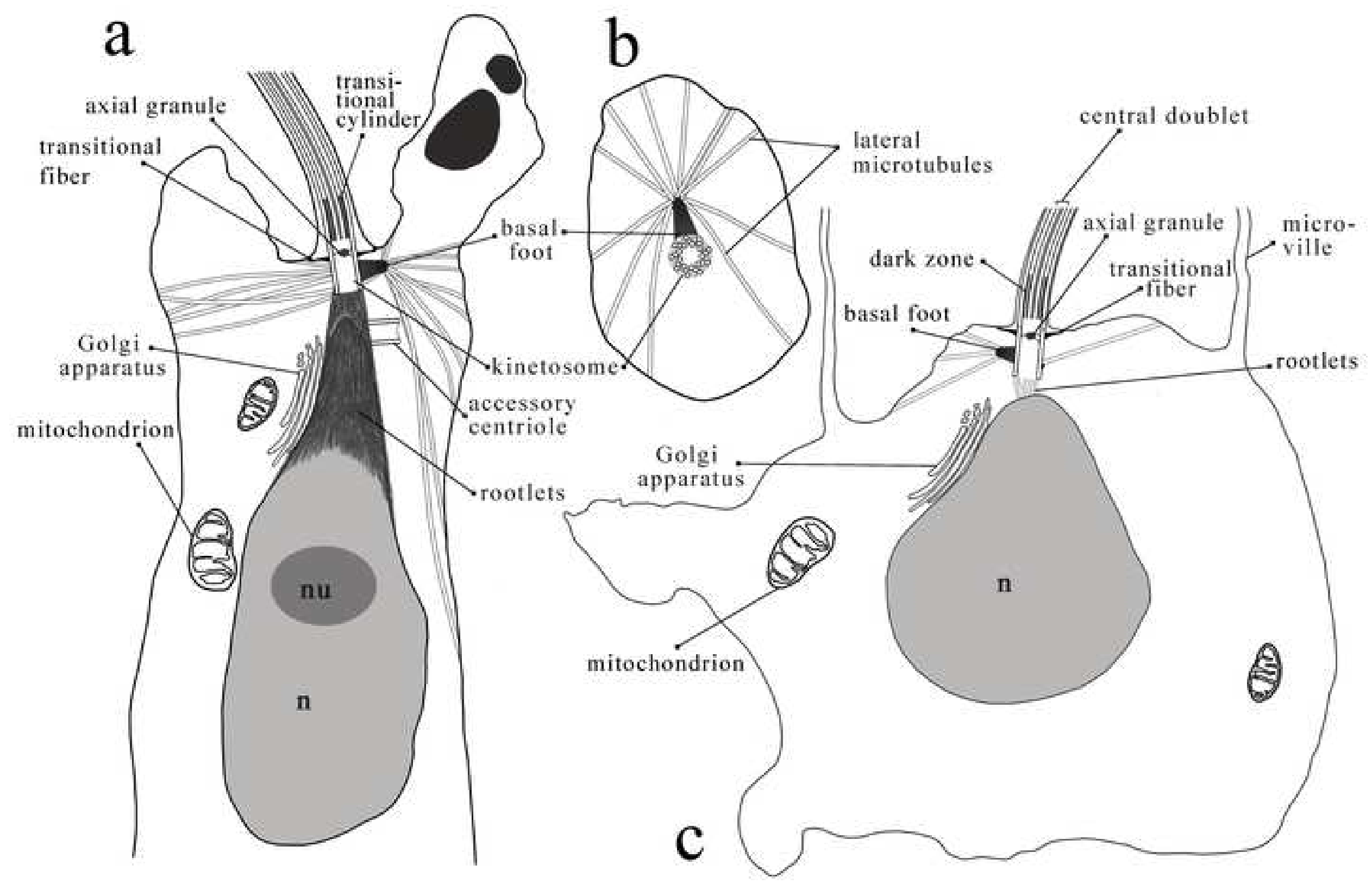

